\title{
TINDAK ILOKUSI EKSPRESIF DAN PRINSIP KESANTUNAN \\ DALAM PROGRAM NIPPON HOUSOU KYOUKAI WORLD
}

\section{EXPRESSIVE ILLOCUTIONARY ACTS AND POLITENESS ON NIPPON HOUSOU KYOUKAI WORLD PROGRAM}

\author{
Moh. Faizal Fuad Aziz \\ Universitas Pesantren Tinggi Darul U'lum Jombang \\ fuad_al_azizu@yahoo.co.id
}

\begin{abstract}
Abstrak
Penelitian ini bertujuan untuk mengaji tindak ilokusi ekpresif yang merepresentasikan prinsip kesantunan dalam program NHK World. Penelitian tindak ilokusi ekspresif ini berlandaskan pada teori Leech (1993). Penelitian ini merupakan penelitian kualitatif. Metode yang digunakan dalam penelitian ini adalah analisis deskriptif. Sumber data dalam penelitian ini adalah rekaman program NHK World. Data pada penelitian ini berupa tuturan-tuturan yang mengandung tindak ilokusi ekspresif. Teknik pengumpulan data menggunakan teknik simak dan catat. Tindak ilokusi ekspresif terdiri dari ucapan terima kasih, permintaan maaf, dan rasa senang. Klasifikasi tersebut direpresentasikan dalam empat maksim kesantunan yaitu kerendah hatian, pujian, kesepakatan, dan simpati.
\end{abstract}

Kata Kunci : tindak Ilokusi Ekspresif, prinsip kesantunan

\begin{abstract}
This study aims to assess information about expressive illocutionary acts that represent the principles of politeness in the NHK World program. Research based on the theory of Leech (1993). This is research of qualitative. In this research used method of descriptive analysis. And this research source of data is a recording NHK World program. While the data in this study are utterances containing expressive illocutionary acts. Data collection technique which used by observing method. Acts of illocutionary expressive consists of acknowledgments, apologies, and pleasure. The classifications represented in four maxims of politeness, that maxim humility, praise, agreement, and sympathy.
\end{abstract}

Key Words : expressive illocutionary acts, politeness.

\section{PENDAHULUAN}

Bahasa dan manusia merupakan dua hal yang berhubungan. Menurut Chaer dan Agustina (2004:14), bahasa adalah alat untuk komunikasi. Sesuai dengan pernyataan tersebut keberadaan 
bahasa sebagai alat komunikasi penting karena dengan bahasa manusia dapat mengekspresikan pikirannya.

Ada dua pihak yang saling bertukar informasi dalam berkomunikasi yaitu pemberi informasi (penutur) dan penerima informasi (lawan tutur). Bahasa yang digunakan dalam komunikasi hendaknya dapat mendukung maksud secara jelas agar apa yang dipikirkan, diinginkan, atau dirasakan itu dapat diterima oleh lawan tutur. Dalam menyampaikan sebuah informasi, penutur tidak selalu menggunakan tuturan yang lengkap. Terkadang, meskipun dengan tuturan yang sederhana, maksud dan tujuannya tersampaikan, akan membuat lawan tutur lebih mudah mengerti informasi yang disampaikan oleh penutur.

Disiplin ilmu yang mengkaji segala aspek tentang kebahasaan tercakup dalam bidang linguistik. Linguistik sebagai ilmu kajian bahasa memiliki beberapa cabang, di antaranya adalah fonologi, morfologi, sintaksis, semantik, dan pragmatik. Menurut Wijana (1996:1), keempat cabang linguistik yang pertama mempelajari struktur bahasa secara internal, sedangkan pragmatik adalah cabang ilmu bahasa yang mempelajari struktur bahasa secara eksternal, yakni bagaimana kesatuan bahasa itu digunakan di dalam komunikasi. Struktur bahasa secara eksternal meliputi konteks, maksud, dan tujuan penutur menuturkan sebuah tuturan kepada lawan tuturnya, sehingga dapat dikatakan bahwa pragmatik mengkaji konteks dan maksud sebuah tuturan dalam berkomunikasi. Seperti yang dicontohkan Wijana dan Rohmadi (2009:41-42), dalam tuturan “Tolong!" dan "Dapatkah Anda menolong saya?"akan digunakan dalam situasi dan kondisi yang berbeda. Jika dalam keadaan darurat, lebih tepat digunakan tuturan pertama, sedangkan orang yang memohon bantuan orang lain dalam situasi yang tidak begitu mendesak akan cenderung menggunakan tuturan yang kedua.

Levinson (dalam Rahardi, 2003:12) berpendapat bahwa pragmatik sebagai studi perihal ilmu bahasa yang mempelajari relasi-relasi antara bahasa dengan konteks tuturannya. Konteks tuturan yang dimaksud telah tergramatisasi dan terkodifikasikan sedemikian rupa, sehingga sama sekali tidak dapat dilepaskan begitu saja dari struktur kebahasaannya. Menurut Yule (2006:5), pragmatik adalah studi tentang hubungan antara bentuk-bentuk linguistik dan pemakai bentuk-bentuk itu. Seseorang dapat bertutur kata tentang makna yang dimaksudkan orang, asumsi, maksud, tujuan, dan jenis-jenis tindakan yang diperlihatkan ketika sedang berbicara. Misalnya dua orang teman yang sedang bercakap-cakap mungkin menyatakan secara tidak langsung beberapa hal tentang apa yang disampaikan. Dari dua pengertian di atas, dapat disimpulkan bahwa pragmatik adalah ilmu bahasa yang memepelajari kondisi peggunaan bahasa manusia yang pada dasarnya sangat ditentukan oleh konteks yang mewadahi dan melatarbelakangi bahasa itu. Kajian pragmatik adalah makna satuan lingual secara eksternal yang terikat konteks dan bentuk untuk memahami maksud dari penutur.

Grice (dalam Nadar 2009:43) menyebutkan dalam prinsip kerja sama bahwa dalam interaksi sehari-hari penutur dan lawan tutur memiliki semacam kewajiban untuk saling menyenangkan hati 
masing-masing. Namun berbeda dengan Leech. Leech (dalam Nadar 2009:28) berpendapat bahwa dalam pertukaran tuturan peserta tutur tidak hanya harus menghormati prinsip-prinsip kerja sama, tetapi juga mengindahkan prinsip-prinsip kesantunan. Artinya, dalam komunikasi kesantunan juga berperan penting. Suatu tuturan yang disampaikan tidak boleh meyinggung perasaan lawan tutur, sehingga prinsip kesantunan hendaknya tidak diabaikan.

Agar seorang penutur dapat diterima dengan baik pada waktu menyampaikan suatu informasi, penutur tersebut harus mengikuti dan mematuhi norma-norma kesantunan yang berlaku dalam kehidupan masyarakat. Prinsip kesantunan juga diperlukan untuk menjaga keseimbangan sosial dan keramahan hubungan dalam berkomunikasi. Dengan demikian, peserta pertuturan hendaknya berusaha menghindari ungkapan yang tidak menyenangkan dari lawan tuturnya agar komunikasi berjalan lancar sehingga individu merasa diperlakukan secara santun.

Komunikasi bukan hanya sekedar mengekspresikan pernyataan kebahasaan saja, melainkan ada suatu tindakan yang terkandung dalam suatu tuturan, hal inilah yang dikenal dengan sebutan speech act atau tindak tutur. Menurut Chaer (2010:27), tindak tutur adalah tuturan dari seseorang yang bersifat psikologis dan yang dilihat dari makna tindakan dalam tuturannya itu. Hal ini sejalan dengan pendapat Hashiuchi (dalam Zaenal 2011:5) juga menjelaskan pengertian tindak tutur yaitu:

発話というものは単にものを言うことだけでなく，その内容に即した行為をも含ん でいるというのが論旨である。

Hatsuwa to iu mono wa tan ni mono o iu koto dake de naku, sono naiyou ni sokushita koui o mono fundeiru to iu no ga ronshi de aru.

'Yang dimaksud tindak tutur adalah tidak hanya menuturkan sesuatu secara sederhana, tetapi di dalamnya terkandung suatu tindakan sesuai dengan isi tindak tutur.'

Berdasarkan kedua pengertian tersebut, tindak tutur adalah tuturan yang diutarakan oleh penutur tidak semata-mata hanya diutarakan, melainkan adanya suatu tindakan yang diinginkan oleh penutur kepada lawan tutur. Seperti pada contoh berikut, ketika seseorang mengucapkan tuturan "Ada film bagus" pada temannya, tuturan tersebut tidak hanya bentuk kebahasaan semata yang memberitahukan bahwa ada film bagus, melainkan ada suatu maksud dan tujuan penutur yaitu bermaksud mengajak temannya untuk menonton film bersama.

Keberhasilan suatu komunikasi antara penutur dan mitra tutur dapat ditentukan oleh terlaksananya prinsip-prinsip yang terdapat pada pragmatik, di antaranya yaitu penerapan prinsip kerjasama dan prinsip kesantunan. Prinsip kesantunan ini akan terfokus pada tuturan dari penutur dan lawan tutur serta orang yang dibicarakan penutur karena dalam berkomunikasi akan selalu melibatkan banyak aspek di luar bahasa termasuk aspek interpersonal para penuturnya.Pada kegiatan 
bertutur yang sesungguhnya, orang selalu mempertimbangkan apakah tuturan yang digunakan itu tergolong sebagai tuturan santun atau tidak santun (Rahardi, 2005:121). Sejalan dengan pendapat Rahardi, lee (1995:343) menyatakan bahwaprinsip kesantunan untuk memperlancar komunikasi berbahasa.

Menurut Leech (dalam Koizumi, 1995:342), terdapat 6 pedoman maksim yang mendasari prinsip kesantunan, namun yang biasanya diungkapkan dengan tuturan ekspresif terdapat 4 pedoman maksim, yaitu sebagai berikut :

Peserta tutur diharapkan dapat besikap rendah hati dengan cara mengurangi pujian terhadap dirinya sendiri. Orang akan dikatakan sombong dan congkak hati apabila di dalam kegiatan bertutur selalu memuji dan mengunggulkan dirinya sendiri. 自己への賞賛を最小し、非 難を最大とする。Jiko he no shousan o saishou shi, hinan o saidai to suru 'meminimalkan pujian untuk diri sendiri dan memaksimalkan celaan/kritik untuk diri sendiri'. Wijana dan Rohmadi (2009:55) berpendapat bahwa maksim kerendahhatian biasanya diungkapkan dengan tuturan ekspresif dan tuturan asertif. Berikut ini adalah contoh tuturan ekspresif

$$
\begin{aligned}
& \text { A : 本当に 助かりました。感謝します。 } \\
& \text { hounto ni tasukarimashita. Kansha shimasu. } \\
& \text { Benar-benar tertolong terimakasih } \\
& \text { 'Aku benar-benar tertolong. Terima kasih ya.' }
\end{aligned}
$$

(New Approach, 2004:135)

Percakapan (2) menunjukkan bahwa pada tuturan (A) telah memenuhi prinsip kesantunan terutama maksim kerendahan hati. Tuturan tersebut berusaha meminimalkan pujian untuk dirinya dengan menyatakan rasa terima kasih atas kebaikan yang diberikan oleh lawan tutur. Awalnya, (A) merasa dapat menyelesaikan semua pekerjaannya sendiri, lawan tutur memutuskan untuk membantu (A) sehingga pekerjaannya cepat terselesaikan. (A) merasa senang karena sudah dibantu dalam menyelesaikan pekerjaannya. Tuturan tersebut dianggap santun karena walaupun tidak mengharapkan bantuan, (A) tetap menyampaikan rasa terima kasih sebagai balasan kebaikan lawan tutur.

Orang akan dapat dianggap santun apabila dalam bertutur selalu berusaha memberikan pujian kepada pihak lain. 相手の非難を最小とし、賞賛を最大とする。Aite no hinan o saishou toshi, shousan o saidai to suru (Meminimalkan celaan untuk orang lain dan memaksimalkan pujian untuk orang lain). Wijana dan Rohmadi (2009:54) berpendapat 
bahwa maksim pujian biasanya diungkapkan dengan tuturan ekspresif dan tuturan asertif. Berikut ini adalah contoh tuturan ekspresif .

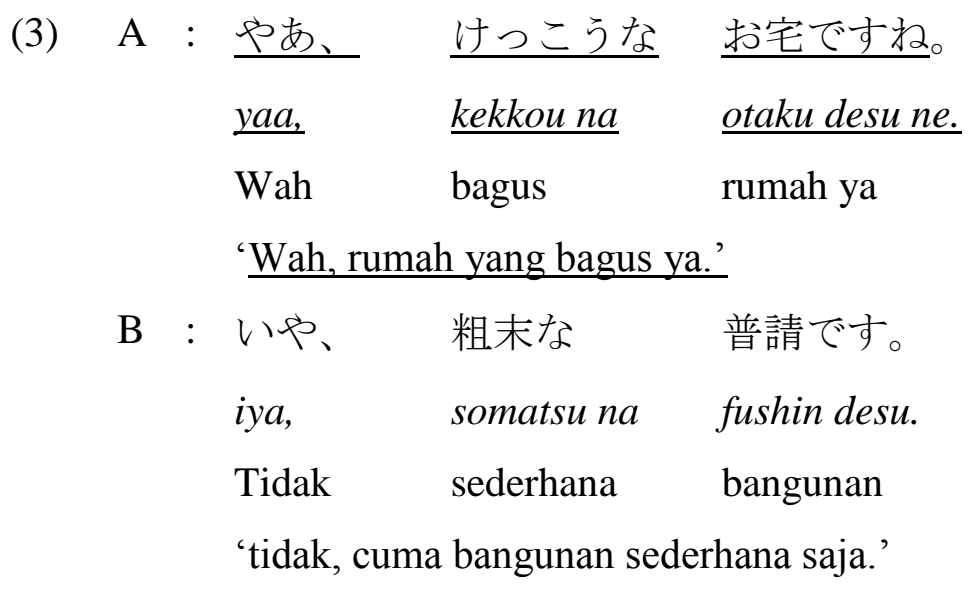

(Koizumi, 1995:342)

Pada percakapan tersebut, tuturan yang disampaikan oleh (A) memenuhi prinsip kesantunan terutama maksim pujian. (A) berusaha memaksimalkan pujian untuk orang lain dengan memuji kondisi rumah (B). Tuturannya sudah menunjukkan kesantunan dengan memperkecil celaan kepada lawan tutur. Hal ini dilakukan agar komunikasi antara keduanya berjalan lancar sehingga tidak terjadi ketersinggungan.

Kesantunan dalam bahasa Jepang disebut dengan keigo. Menurut Minoru (dalam Sudjianto, 1996:124), keigo adalah bahasa atau kata-kata khusus yang digunakan untuk menunjukkan kerendahhatianpenutur dan untuk menyatakan rasa hormat penutur terhadap petutur. Keigo merupakan ragam bahasa sopan yang dalam penggunaannya memperhatikan situasi, siapa lawan bicara dan siapa yang dibicarakan. Tingkatan tuturan bahasa Jepang menurut Nakao (1997:143) ditentukan berdasarkan parameter berikut ini.

1. Usia (nenrei), dengan melibatkan apakah tua atau muda, senior atau junior. Orang yang lebih muda menggunakan ragam bahasa sopan kepada yang lebih tua untuk menunjukkan rasa hormatnya.

2. Status posisi (chii), meliputi apakah atasan atau bawahan, dosen atau mahasiswa. Di Jepang, hubungan atasan - bawahan sangat terlihat dari bahasa yang mereka gunakan.

3. Gender (sei), meliputi apakah laki-laki atau perempuan. Wanita lebih banyak menggunakan keigo karena cara pandang masyarakat Jepang terhadap perempuan. Namun demikian, laki-laki juga menggunakan keigo terhadap perempuan agar terlihat santun. 
4. Tingkat keakraban (shinso), apakah orang yang berada di lingkungan sendiri (orang dalam) atau sebaliknya (orang luar). Semakin akrab seseorang dengan lawan bicaranya, semakin rendah bahasa sopan yang digunakan.

5. Bentuk kalimat (buntai) apakah bahasa percakapan sehari-hari, bahasa yang digunakan dalam seminar, atau bahasa yang digunakan dalam rapat, formal dan nonformal (koushi), apakah bahasa yang digunakan bersifat umum atau pribadi.

Konteks penting dalam menafsirkan berbagai macam teks. Konteks sangat menentukan makna suatu ujaran. Rahardi (2005:50) berpendapat bahwa konteks adalah segala latar belakang pengetahuan yang dimiliki bersama oleh penutur dan mitra tutur serta yang menyertai dan mewadahi sebuah tuturan. Keberadaan konteks sangat penting dalam berkomunikasi, karena jika penutur menyampaikan sebuah informasi dan lawan tutur tidak memahami konteks yang terdapat dalam komunikasi tersebut, maka maksud dan tujuan penutur tidak akan tersampaikan dengan baik kepada lawan tutur. Konteks berfungsi untuk memperlacar tuturan karena konteks mempengaruhi kemampuan lawan tutur dalam menginterpretasikan suatu tuturan yang dimaksud oleh penutur.

Kesantunan berbahasa akan mengatur apa yang harus dikatakan pada waktu dan keadaan tertentu kepada lawan tutur berkenaan dengan status sosial budaya masyarakat tersebut. Realitas sosial akan berpengaruh terhadap penggunaan bahasa. Perubahan bentuk kalimat saat digunakan dalam berkomunikasi berpengaruh terhadap nilai rasa dari kalimat tersebut, disesuaikan kepada siapa penutur berhadapan atau berbicara.

NHK merupakan singkatan dari Nippon Housou Kyoukai adalah satu-satunya lembaga penyiaran publik di Jepang. NHK memulai siaran radio pada tahun 1925. Perusahaan ini didanai oleh iuran televisi yang dibayar pemilik pesawat televisi agar dapat memberikan materi siaran yang bebas dari pengaruh politik atau organisasi swasta serta memprioritaskan opini khalayaknya. $N H K$ saat ini melakukan siaran di 4 saluran televisi dan 3 saluran radio dalam negeri. Saluran TV Umum dan TV Pendidikan untuk layanan TV teresterial serta 3 saluran radio dalam negeri menyajikan berita, program pendidikan, hiburan keluarga dan sebagainya. Dua saluran TV ini menyajikan program yang fleksibel guna memenuhi kebutuhan yang luas. NHK WORLD menyelenggarakan layanan penyiaran internasional. NHK WORLD adalah layanan penyiaran internasional NHK. NHK mengelola layanan televisi dan radio internasional serta internet. Seluruh layanan ini dikenal sebagai NHK WORLD.

NHK World merupakan media pembelajaran bahasa Jepang yang terdapat sebuah percakapan-percakapan yang menceritakan kehidupan sehari-hari di Jepang. Dalam program NHK World tersebut peneliti mengambil data pada edisi ketiga bulan april tahun 2015dengan 48 adegan percakapan. Setelah melakukan pengamatan lebih dalam terhadap percakapan pada program $N H K$ World, ditemukan banyak tuturan yang mengandung kesantunan berbahasa Jepang. Banyaknya tuturan yang mengandung tindak ilokusi ekspresif dalam percakapan tersebut, membuat peneliti 
lebih tertarik untuk menganalisis lebih mendalam, karena sumber data penelitian ini merupakan salah satu bentuk media pembelajaran bahasa Jepang dimana dalam pengajaran bahasa Jepang belum diterapkan secara keseluruhan, sehingga bisa berkontribusi terhadap dunia pendidikan bahasa Jepang. Berdasarkan uraian di atas fokus dalam penelitian ini adalah tindak ilokusi ekspresif yang merepresentasikan prinsip kesantunan berbahasa Jepang dalam program Nippon Housou Kyoukai World.

\section{METODE PENELITIAN}

Penelitian ini menggunakan pendekatan kualitatif karena data dalam penelitian ini berupa kata-kata bukan angka. Data kualitatif yang diperoleh dalam penelitian ini berupa tuturan yang mengandung tindak ilokusi ekspresif yang merepresentasikan prinsip kesantunan. Jenis penelitian ini adalah deskriptif karena objek penelitian ini berupa tuturan-tuturan para tokoh dalam percakapan. Penelitian deskriptif menyajikan hasil analisis dalam bentuk deskripsi. Sumber data penelitian ini adalah rekaman program NHK World Edisi ketiga, yaitu pada bulan April tahun 2015 sebanyak 48 adegan, dengan tokoh utamanya Anna, dari Thailand yang sedang studi di Jepang. Sumber data yang digunakan dalam penelitian ini juga dipakai untuk media pembelajaran bahasa Jepang melalui online. Fokus permasalahan dalam penelitian ini, diperlukan data berupa ujaran yang tergolong tindak ilokusi ekspresif ditinjau dari prinsip kesantunan Leech (maksim kerendahan hati, maksim pujian, maksim kesepakatan, dan maksim simpati) dari program NHK World.

\section{PEMBAHASAN}

Tindak ilokusi ekspresif yang merepresentasikan prinsip kesantunan. Berdasarkan penganalisisan data ditemukan tindak ilokusi yang merepresentasikan prinsip kesantuan pada program $N H K$ World. Diketahui jumlah tuturan yang mengandung tindak ilokusi ekspresif sebanyak 18 data. Selanjutnya untuk maksim yang paling banyak muncul yaitu maksim pujian. Tindak ilokusi ekspresif berfungsi menyatakan atau menunjukkan sikap psikologis dari penuturnya. Adapun tindak ilokusi ekspresif diklasifikasikan dalam beberapa jenis, yaitu terimakasih, permintaan maaf, memberkati, dan senang. Selanjutnya agar lebih spesifik maka berikut ini disajikan data berdasarkan klasifikasi tindak ilokusi ekspresif yang dianggap representatif untuk mewakili karakteristik keseluruhan data dalam bentuk tabel. 
Tabel 1.

Klasifikasi Data Tindak Ilokusi Ekspresif

\begin{tabular}{|c|l|l|}
\hline NO & \multicolumn{1}{|c|}{ JENIS } & \multicolumn{1}{c|}{ MAKSIM } \\
\hline 1 & Ucapan Terimakasih & Pujian \\
\hline 2 & Permintaan maaf & Kerendahhatian \\
\hline 3 & Memberkati & Simpati \\
\hline 4 & Senang & Kesepakatan \\
\hline
\end{tabular}

Pada tabel di atas, terdapat empat jenis tindak ilokusi ekspresif yang akan dideskripsikan sebagai berikut.

\subsection{Ucapan Terimakasih}

Data tindak ilokusi ekspresif jenis ucapan terimakasih yang mengandung maksim pujian sebagai berikut.

(6) Yamada

クオンさん。 これが
kuon san. $\quad$ kore ga
kuon. $\quad$ Ini
Kuon,ini kartu nama Anda
ありがとうございます。
arigatou gozaimasu.
terimakasih.
'Terimakasih.'

あなたの名刺です。

anata no meishidesu.

$\begin{array}{llll}\text { kuon san. } & \text { kore ga } & \text { anata no } & \text { meishi desu. } \\ \text { kuon. } & \text { Ini } & \text { punya anda } & \text { kartu nama } \\ \text { Kuon,ini kartu nama Anda } & & \end{array}$

Kuon

Terimakasih.

(NHK.11.A2)

Berdasarkan pada konteks situasi tutur di atas merupakan tuturan di kantorketika Kuon datang untuk pertama kali. Tuturan yang bergaris bawah merupakan salah satu bentuk tindak ilokusi, yaitu tindak ilokusi ekspresif. Sebagaimana menurut teori Searle yang mengatakan bahwa bentuk tindak ilokusi ekspresifberfungsi menyatakan atau menunjukkan sikap psikologis atau ekspresi dari penuturnya seperti meminta maaf, berterimakasih, berduka cita dan doa restu. Pada tuturan tersebut disampaikan bahwa Kuon mengucapkan terimakasih kepada Ibu Yamada yang telah memberi sebuah kartu nama kepada Kuon. Kartu nama merupakan identitas yang sangat penting, terutama dalam kalangan bisnis. Karena dengan kartu nama, orang lain lebih mudah untuk mengingat orangdan sebagai tambahan relasi untuk di masa yang akan datang.

Dalam tuturan tersebut juga terpenuhi prinsip kesantunan. Tuturan tersebut termasuk dalam maksim pujian. Hal ini sesuai dengan teori dari Leech (1993) yang mengatakan bahwa dalam maksim pujian agar meminimalkan celaan untuk orang lain dan memaksimalkan pujian untuk orang lain. Ibu Yamada terlihat sangat menerima kehadiran Kuon yang berasal dari Vietnam di kantornya. Di hari pertama kerja, Kuon sudah disambut dan diberikan penjelasan mengenai pekerjaan yang harus Kuon lakukan selama berada di Jepang. Mereka jadi saling bertukar pengalaman dalam urusan bisnis demi kemajuan perusahaannya. 
Pada tuturan tersebut, karena Kuon sebagai bawahan dalam mengucapkan rasa terimakasih kepada atasan, menggunakan bentuk - masu (ます) yaitu arigatou gozaimasu(ありがとうござい ます). Jika Kuon hanya mengatakan "arigatou" saja, hal ini dianggap kurang santun. Karena ungkapan seperti ini bisa diucapkan kepada sesama teman atau yang lebih muda dari penutur.

\subsection{Permintaan Maaf}

Data tindak ilokusi ekspresif jenis permintaan maaf yang mengandung maksim kerendahhatian sebagai berikut.

$\begin{array}{rlllll}\text { (7) Leo } \quad: & \text { お待たせ } & \text { しました。 } & & \\ & & & \\ & \text { menunggu } \text {-matase } & \text { shi-mashita. } & & & \\ & \text { Maafkan telah menunggu saya. } & & & \\ \text { Aki } \quad: & \text { まだ } & \text { 大丈夫。 } & \text { 全員 } & \text { そろってない } & \text { から。 } \\ & \text { Mada } & \text { daijôbu. } & \text { Zen in } & \text { sorotte nai } & \text { kara. } \\ & \text { belum } & \text { Tidak apa-apa } & \text { semua } & \text { Tidak kumpul } & \text { karena } \\ & & \text { Tidak apa-apa, kamu belum terlambat. Belum kumpul semuanya. }\end{array}$

(NHK.08.A58)

Tuturan tersebut digunakan ketika ingin meminta maaf karena sudah membuat orang menunggu. Tuturan yang bergaris bawah merupakan salah satu bentuk tindak ilokusi, yaitu tindak ilokusi ekspresif. Sebagaimana menurut teori Searle yang mengatakan bahwa bentuk tindak ilokusi ekspresifberfungsi menyatakan atau menunjukkan sikap psikologis atau ekspresi dari penuturnya seperti meminta maaf, berterimakasih, berduka cita dan doa restu. Pada tuturan tersebut tergolong jenis permintaan maaf. Umumnya ungkapan permintaan maaf menggunakan gomenasai, sumimasen, moshi wake arimasen. Tuturan di atas menggunakan prefiks o (お $\sim)$ yang menjadi o-matase shimashita untuk memperhalus makna.

Dilihat dari prinsip kesantunan, tuturan tersebut mengandung maksim kerendahhatian. Karena penutur mengakui kesalahannya, yaitu telah membuat orang lain menunggu. Sebagaimana menurut pendapat Leech dalam maksim kerendahhatian, diharapkan meminimalkan pujian untuk diri sendiri dan memaksimalkan celaan/kritik untuk diri sendiri.

\subsection{Memberkati}

Data tindak ilokusi ekspresif jenis memberkati yang mengandung maksim simpati sebagai berikut. Kemudian data yang menunjukkan ilokusi ekspresif jenis memberkati disajikan pada contoh berikut.

(8) Leo ：あきさん、ご結婚はいつですか?

Aki - san, go - kekkon - wa itsu - desu - ka?

Aki, kapan kamu akan menikah?

Aki ： 来年の 4 月の予定なの。

Rainen - no shigatsu - no yotê - nano.

Rencananya bulan april tahun depan. 


$\begin{array}{rll}\text { Leo } \quad: \quad & \text { ぞうか } & \text { お幸せに! } \\ & \text { Dô - } k a & o-\text { shiawase - ni! } \\ & \text { bagaimana } & \text { bahagia } \\ & \text { 'Semoga berbahagia!' }\end{array}$

(NHK.08.A93)

Tuturan tersebut antara Leo dan Mika. Mika akan melangsungkan pernikahannya dalam waktu dekat. Sehingga dalam percakapan Leo mendoakan Mika "semoga berbahagia". Tuturan tersebut termasuk dalam tindak ilokusi ekspresif jenis memberkati. Sebagaimana menurut teori Searle yang mengatakan bahwa bentuk tindak ilokusi ekspresifberfungsi menyatakan atau menunjukkan sikap psikologis atau ekspresi dari penuturnya seperti meminta maaf, berterimakasih, berduka cita dan doa restu.

Jika ditinjau dari prinsip kesantunan, tuturan tersebut mengandung maksim simpati. Karena Leo ikut merasa bahagia karena temannya akan menikah. Sebagaimana menurut pendapat Searle yaitu meminimalkan rasa antipati antara diri sendiri dan orang lain, serta memaksimalkan rasa simpati antara diri sendiri dan orang lain. Ikut berbahagia atas kebahagiaan yang didapat oleh orang lain merupakan wujud rasa simpati diri sendiri terhadap orang lain. Selain itu, tuturan tersebut juga menggunakan prefiks o yang berfungsi sebagai penghalus makna pada kata $o$-shiawaseni.

\subsection{Senang}

Data tindak ilokusi ekspresif jenis senang yang mengandung maksim kesepakatan sebagai berikut.

(9) Kuon

$\begin{array}{lll}\text { ： 今日は } & \text { ありがとうございました。 } & \text { 楽しかったです。 } \\ & \text { Kyô wa } \quad \text { arigatô gozaimashita. } & \text { Tanoshikatta desu. } \\ \text { Hari ini } & \text { terimakasih } & \text { senang } \\ \text { 'Terima kasih banyak untuk hari ini. Saya senang sekali.' }\end{array}$

Ibu Kontrakan： こちらこそ、来てくれてありがとう。

Kochirakoso, kite kurete arigatô.

Kami juga senang. Terima kasih sudah datang.

(NHK.11.A41)

Tuturan tersebut antara Kuon dan Ibu pemilik kontrakan. Kuon menyatakan rasa senangnya karena sudah mendapat banyak bantuan dari Ibu pemilik kontrakan.tuturan tersebut termasuk tindak ilokusi ekspresif jenis ungkapan senang, karena Kuon mengucapkan Tanoshikatta desu senang sekali. Sebagaimana menurut teori Searle yang mengatakan bahwa bentuk tindak ilokusi ekspresifberfungsi menyatakan atau menunjukkan sikap psikologis atau ekspresi dari penuturnya seperti meminta maaf, berterimakasih, berduka cita dan doa restu.

Ditinjau dari prinsip kesantunan, tuturan tersebut mengandung maksim kesepakatan, karena Ibu Kontrakan secara tidak langsung juga senang dengan kedatangan Kuon dengan mengucapkan terimakasih dan ungkapan rasa senangnya. 


\section{KESIMPULAN}

Berdasarkan pembahasan di atas dapat diambil simpulan, yaitu tindak ilokusi ekpresif yang merepresentasikan prinsip kesantunan dalam Program NHK World berdasarkan teori Leech, yaitu tindak ilokusi ekspresif terdiri dari ucapan terima kasih, permintaan maaf, dan rasa senang. Klasifikasi tersebut kemudian direpresentasikan dalam enam maksim kesantunan, yaitu maksim kerendahhatian, pujian, kesepakatan, simpati, kebijaksanaan, dan kedermawanan. Tindak ilokusi ekspresif mengandung maksim kerendahan hati, maksim kesepakatan, dan maksim simpati. Penelitian ini hanya dibatasi pada tindak ilokusi ekspresif yang merepresentasikan prinsip kesantunan. Diharapkan ada penelitian lebih lanjut yang lebih spesifik mengenai tindak ilokusi yang melanggar prinsip kesantunan atau ragam kesantunan bahasa Jepang dalam bentuk imperatif yang mengandung banyak tuturan yang santun sesuai dengan konteksnya. Penelitian ini juga bisa diimplementasikan ke dalam pengajaran bahasa Jepang pada pembahasan kesantunan berbahasa Jepang.

\section{REFERENSI}

Chaer, Abdul. 2010. Kesantunan Berbahasa. Jakarta: Rineka Cipta.

Chaer, Abdul dan Leonie Agustina. 2004. Sosiolinguistik Perkenalan Awal. Jakarta: Rineka Cipta.

Chaer, Abdul dan Leonie Agustina. 2010. Sosiolinguistik Perkenalan Awal. Jakarta: Rineka Cipta.

Yule, George. 2006. Pragmatik. Yogyakarta: Pustaka Pelajar.

Koizumi. 1995.「日本語教師のための語学入門」大修館長.

Leech, Geofrrey. 1993. Prinsip-prinsip Pragmatik. Jakarta: UI Press.

Mahsun. 2005. Metode Penelitian Bahasa : Tahapan Strategi, Metode, dan Tekniknya. Jakarta:

Nadar, F.X. 2009. Pragmatik dan Penelitian Pragmatik. Yogyakarta: Garaha Ilmu.

Nakao, toshio. 2002. Shakai gengogaku gairon. Tokyou: kuroshio.

Rahardi, Kunjana. 2005. Pragmatik Kesantunan Imperatif Bahasa Indonesia. Jakarta: Erlangga.

Sudjianto, 1996. Gramatika Bahasa Jepang Modern Seri A. Jakarta: Kesaint Blanc.

Tim Penyusun. 2004. New Approach Chukyuu Nihongo. Japan: Nihongo Kenkyusha. 
Toshio, Nakao. 1997. Shakai Gengogaku Gairon - Nihongo to Eigo no Rei de Manabu Shakai Gengogaku. Tokyo: Kuroshio Shuppan.

Wijana, I Putu Dewa. 1996. Dasar-Dasar Pragmatik. Yogyakarta: Andi Yogya.

Wijana, I Putu Dewa dan Muhammad Rohmadi. 2009. Analisis Wacana Pragmatik. Surakarta: Yuma Pustaka.

http://www3.nhk.or.jp/nhkworld/indonesian/aboutus/(diakses pada tanggal 24 Februari 2017 